\title{
Review
}

\section{Democracy and disenfranchisement: The morality of electoral exclusions}

\author{
Claudio López-Guerra \\ Oxford University Press, Oxford, 2014, x+189pp., ISBN: 978-0198705789 \\ Contemporary Political Theory (2017) 16, 137-140. doi:10.1057/cpt.2015.53; \\ advance online publication 6 October 2015
}

Who should be granted the right to vote? This long-standing question is answered, and all its complexities addressed, in Claudio López-Guerra's book about the morality of electoral exclusions. The book's declared objective is to formulate a complex criticism of what he calls the Conventional Suffrage Doctrine, according to which minors, mentally impaired, non-citizen residents and convicted criminals should be excluded, and ignorant people and expatriates should be included in the franchise. His efforts are directed to theoretically demonstrate the opposite case. López-Guerra's Critical Suffrage Doctrine defends the claim that some of those who, it is typically assumed, are justifiably excluded (for example, children) should be included and vice versa (for example, ignorant people).

The book can be seen as divided into two distinctive parts. The first part is committed to justifying the electoral exclusion of political incompetents by presenting an alternative to universal suffrage. López-Guerra disputes the idea that the right to vote is a fundamental right by arguing that this claim presupposes too many contentious points found in the discussion on disenfranchisement. In contrast, he pursues a problem-driven political philosophical enquiry about the question of who must be enfranchised, 'in which the relevant moral issues are confronted as they arise' (p. 11), that departs from the basis that voting is not a basic right. This distinctive methodological point of departure allows him to answer the question about who should be enfranchised free from the constraints that theory-driven approaches present for institutional design, public persuasion and an 'all thingsconsidered assessment of social institutions' (p. 13).

His particular challenge to universal suffrage is developed in Chapter 2 and adopts the form of the enfranchisement lottery, a combination of two institutions. The first one is a lottery for the selection and enfranchisement of a non-biased mini public, whose performance, the author claims, would be equivalent on epistemic terms to the performance of the public under a model of universal suffrage. The second one is a competence-building process to increase the political knowledge of those selected.

(c) 2016 Macmillan Publishers Ltd. 1470-8914 Contemporary Political Theory Vol. 16, 1, 137-140 
After being subjected to this process, this limited franchise would produce better electoral results than universal suffrage because the electors would be better informed. In concrete terms, the 'better results' produced by the franchise optimization are mainly manifested in reducing the electoral chances of corrupt candidates, and, therefore, avoiding unjust rulers. In this sense, he discards an important ideological impact of this process. However, it suffers deficits in the terrain of nonepistemic considerations, two of which are particularly important: political order and the value of the right to vote.

The advantages of universal suffrage for the maintenance of the political order are as important as the weaknesses of the enfranchisement lottery in this very respect. López-Guerra acknowledges that under this system, with a small electorate, the 'risk of capture [of the electors] can be a serious concern in certain contexts' (p. 49) and 'could lead more easily to destabilizing post-electoral conflicts' (p. 50), concluding that as 'a device of allocating political power, universal suffrage is more likely to secure political order' (p. 51). Regarding the value of the right to vote, he acknowledges that disenfranchisement would involve a minor limitation of people's political agency. However, he discards arguments claiming that it would constitute a form of disrespect based mainly on the fact that the enfranchisement lottery is a non-arbitrary institutional model. The author therefore claims that under circumstances of 'strong rule of law and high levels of trust in public institutions' (p. 4) the enfranchisement lottery and universal suffrage would be equally attractive, and the adoption of the former would not be unjust.

This analysis and conclusion will likely draw criticism. Three points of criticism will be mentioned here. First, and in relation to the conclusion, it is unclear how epistemic and non-epistemic considerations can be balanced to conclude that the former's virtues can compensate for the latter's problems. In this regard, the strategy López-Guerra adopts of compartmentalizing the problems and objections might be seen as a weakness rather than a virtue of the argument for the enfranchisement lottery. Second, when analysing the problems of political order, the author does not pay due attention to the crucial phenomenon of the autonomy or isolation of the political elite from society. Looking at the corruptive effects analysed, no serious attention is paid to the control that the uncontrolled political elite would have over all relevant aspects of the lottery (regardless of whether rule of law and public trust is established). For example, exactly in the same way that the political elite define what is shown in the news, they would define what is incorporated into the competencebuilding process. Third, the idea that the right to vote is associated with some form of respect is discarded too quickly. For example, he does not consider factors such as the current historical significance of the right to vote, or shed light on how this would impact the process of transformation from universal suffrage to enfranchisement lottery.

The second part of the book offers some ideas that can guide the fair distribution of the franchise under a regime of universal suffrage. It must be said that it is surprising 
that this second part develops the idea of universal suffrage, an idea that the first part decidedly challenges, and whose premises and virtues are offered only in a negative form as a sort of sparring for the enfranchisement lottery. The explanation to this puzzle can be found in the author's admission that the enfranchisement lottery is unlikely to be implemented in the near future and that other important questions regarding enfranchisement arise in the regime of universal suffrage currently hegemonic in western democracies.

The first of those ideas is the franchise capacity, which is used to analyse the exclusion of children and the mentally impaired in Chapter 3. This is perhaps the most provocative and challenging idea contained in Democracy and Disenfranchisement. The argument for children's inclusion is supported by two claims. On the one hand, the quality of the electoral outputs would not suffer if the voting age is lowered 'or even abolished' (p. 62). On the other hand, non-instrumental considerations demand that everybody who has 'the moral and rational faculty to value the position of being a voter and thus to be hurt by exclusion' must be enfranchised (p. 6). Addressing the problem of determining who has this capacity, López-Guerra answers with the following reasoning: (i) age is always an imperfect mechanism; (ii) if age is going to be used, over-inclusiveness rather than under-inclusiveness must preferred; and (iii) to more accurately determine an age for the acquisition of franchise capacity, studies on developmental psychology must be used. These studies suggest that as early as 10-years-old children have already acquired the 'natural brain capacity' that, according to the author, qualifies them to vote.

The second, more conventionally progressive idea is the replacement of citizenship with residency as the franchise's requirement. Fully argued in Chapter 4, this idea rejects claims for exclusion based on national identity and elaborates a defence of the idea that national citizenship must be constrained by the notion of being 'regularly subject to the legal system of a political unity' (p. 97). The obvious implication of such an idea is the justification of the exclusion of expatriates.

Finally, the third of these ideas - and perhaps the one that will resonate with lawyers and policy-makers' agendas - is the distinction between fairness of allocation of the franchise (who deserves to be enfranchised) and fairness of the operation of the electoral procedures (whose vote would not damage electoral integrity). López-Guerra bases this distinction on a normative position associated with the right to vote that has been relegated to a secondary role by the notion of the vote as power but is prior to it and central to questions of (dis)enfranchisement. This position can be described as the right to be an elector. This right does not give a definitive - all things considered - right-power to vote, because this can be limited by considerations relative to the operation of the electoral process.

This distinction between questions of allocation and questions of operation informs the debate regarding the disenfranchisement of (at least) two classes of persons. First, those who lack the franchise capacity (whose inclusion would not be prescribed or prohibited in allocation grounds) should be excluded because they can 
be instructed to cast their vote in a way that violates the integrity of the election (Chapter 3). Second, those who are serving prison sentences should be excluded when they cannot freely exercise the right to vote but are subject of voting coercion. It must be noted, however, that López-Guerra affirms that convicted criminals can only be disenfranchised within these certain prison conditions. This is because they are residents of the state, and they have the franchise capacity (Chapter 5). In sum, it is the fairness of the electoral process and not the fairness of the allocation of the franchise that may demand the disenfranchisement of prisoners and young children.

To conclude, López-Guerra's theoretical contribution to the question of children's voting is definitely cutting edge, and his ideas about prisoners' voting are persuasive, especially regarding the Third World's problems. However, the more attractive element of the book is the simplicity with which the author carries out a critical but systematic reading of all aspects of the universal suffrage principle by presenting interesting and thought-provoking ideas. This book should be considered both by those interested generally in the political philosophy of elections and those interested in reading a thoughtful and critical analysis of the many categories of exclusion/ inclusion that configure the rules of the franchise.

Pablo Marshall

Universidad Austral, Valdivia, Los Rios, Chile pmarshall@uach.cl 